\title{
The Takai Olefination: Simple Access to E-Alkenyl Halides
}

\section{Key words}

olefination

stereoselectivity

chromium catalysis

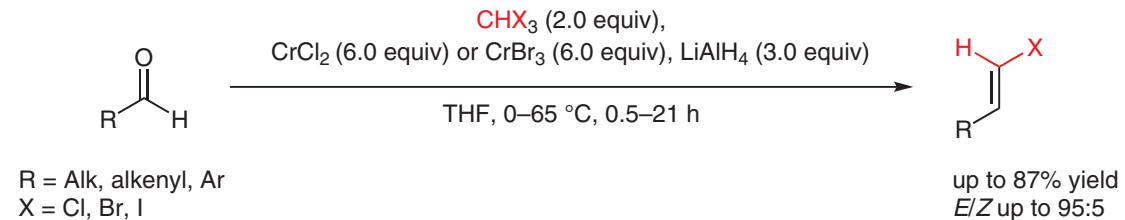

Selected examples:<smiles>I/C=C/c1ccccc1</smiles>

$87 \%$ yield $E / Z=94: 6$<smiles>CCCCCCCC=CCl</smiles>

$76 \%$ yield<smiles>I/C=C/C1CCCCC1</smiles>

$78 \%$ yield<smiles>CC(C)=CCCC(C)CC=CBr</smiles>

$55 \%$ yield<smiles>CC(C)=CCCC(C)CC=CCl</smiles>

$55 \%$ yield $E / Z=92: 8$<smiles>Br/C=C/C=C1CCCCC1</smiles>

$73 \%$ yield $E / Z=81: 19$<smiles>IC=C1CCCCC1</smiles>

$75 \%$ yield<smiles>CCCCOC(=CI)OCCC</smiles>

$51 \%$ yield

Competition experiments:<smiles>CC(=O)CCCCCCCCC(=O)CC(F)F</smiles><smiles>CC(=O)CCCCCCCC/C=C/I</smiles>

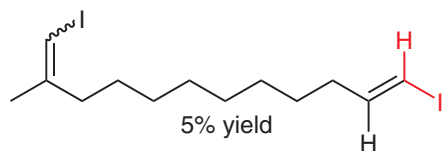

Significance: In 1986 Takai and co-workers developed a simple procedure for the stereoselective preparation of $E$-alkenyl halides from various aldehydes by using an excess of $\mathrm{CrCl}_{2}$ together with a haloform. The selectivity was dependent on the corresponding haloform and decreased in the order $\mathrm{Cl}>\mathrm{Br}>\mathrm{I}$.
Comment: The mild reaction conditions enable highly chemoselective transformations. Thus, the olefination of an aldehyde proceeds smoothly in the presence of ketone moieties. Given the unique chemo- and stereoselectivity, several modifications and improvements of this method have been published over the years. 